\title{
Longitudinal study of risk factors for anaplasmosis and transplacental transmission in herd cattle
}

\section{Estudo longitudinal dos fatores de risco para anaplasmose e transmissão transplacentária em rebanhos bovinos}

\author{
Jenevaldo Barbosa da Silva ${ }^{1 *}$; Gustavo Nunes de Santana Castro ${ }^{2}$; \\ Adivaldo Henrique Fonseca ${ }^{3}$
}

\begin{abstract}
Anaplasma marginale, bacteria that occurs in tropical and subtropical areas throughout the world, is responsible for causing a disease that is one of the most constraint to cattle production in many countries. The present work aimed to investigate potential risk factors for anaplasmosis and the occurrence of transplacental transmission by molecular and serological assays in cattle. A total of 22 calves were randomly sampled and monitored during four years; the presence of infection/exposure to $A$. marginale was assessed by a semi-nested PCR assay targeting msp- 5 gene of $A$. marginale, indirect ELISA for detection of IgG antibodies to $A$. marginale and blood smears. The $A$. marginale infection prevalence data were analyzed in relation to risk factors, using chi-squared, odds ratio and multiple logistic regressions. DNA amplification results revealed a frequency of infection with A. marginale of $41 \%$ $(9 / 22)$ in the newborn calves before colostrum suckling. However, only $14 \%(3 / 22)$ of newborn calves were seropositive for A. marginale. All calves were positive to A. marginale by PCR and microscopic examination of blood smears before the two and fourth month of age, respectively. The main risk factors associated with seroprevalence were breed $(\mathrm{OR}=36.2)$, tick infestation $(\mathrm{OR}=3.44)$ and stocking density $(\mathrm{OR}=3.28)$. The results indicated that exposure of cattle to $A$. marginale was common in dairy herds and endemic instability situation probably is due to inadequate antibody production in cows or genetic variability of pathogen. This study still demonstrated that in addition to transmission of A. marginale by ticks and flies, the transplacental transmission is very important and should be the target of disease control programs in Brazil.
\end{abstract}

Key words: Anaplasma marginale, blood smear, ELISA, PCR

\section{Resumo}

Anaplasma marginale, bactéria que ocorre em regiões tropicais e subtropicais do mundo, é responsável por causar uma das doenças que mais restringem a criação de bovinos em diversos países. O presente trabalho teve como objetivo investigar potenciais fatores de risco para a anaplasmose e a ocorrência de transmissão transplacentária por ensaios moleculares e sorológicos em bovinos. Um total de 22 animais foram amostrados e acompanhados durante quatro anos; a presença de infecção / exposição a A. marginale, foi avaliada pelo semi-nested PCR alvejando o gene MSP-5 de A. marginale, pelo ELISA indireto para a detecção de anticorpos IgG anti-A. marginale e esfregaço sanguíneo. Os dados de prevalência de infecção por $A$. marginale foram analisados em relação aos fatores de risco, usando

\footnotetext{
${ }^{1}$ Discente, Faculdade de Ciências Agrárias e Veterinária, Universidade Estadual Paulista, FCAV/UNESP, Jaboticabal SP, Brasil. E-mail: jenevaldo@hotmail.com

${ }^{2}$ Discente, Universidade Federal Rural do Rio de Janeiro, UFRRJ, Seropédica, RJ, Brasil. E-mail: gnscastro@gmail.com

${ }^{3}$ Prof., Universidade Federal Rural do Rio de Janeiro, UFRRJ, Seropédica, RJ, Brasil. E-mail: adivaldo@ufrrj.br

* Author for corespondence
} 
$\mathrm{X}^{2}$, odds ratio e regressão logística múltipla. A amplificação de DNA revelou uma frequência de infecção por A. marginale de $41 \%$ (9/22) nos bezerros recém-nascidos antes de ingerirem colostro. No entanto, apenas $14 \%(3 / 22)$ dos bezerros recém-nascidos eram soropositivos para $A$. marginale. Todos os bezerros foram positivos para A. marginale por PCR e no exame microscópico de esfregaço sanguíneo, antes do segundo e quarto mês de idade, respectivamente. Os principais fatores de risco associados a soroprevalência foram raça $(\mathrm{OR}=36,2)$, infestação por carrapatos $(\mathrm{OR}=3,44)$ e densidade $(\mathrm{OR}=$ $3,28)$. Os resultados indicaram que a exposição de gado para $A$. marginale era comum nos rebanhos leiteiros e a situação de instabilidade endêmica provavelmente se faz devido à produção inadequada de anticorpos em vacas ou a variabilidade genética do patógeno. Este estudo demonstra ainda que, além da transmissão de $A$. marginale por carrapatos e moscas, a transmissão transplacentária é muito importante e deve ser alvo de programas de controle da doença no Brasil.

Palavras-chave: Anaplasma marginale, esfregaço sanguíneo, ELISA, PCR

\section{Introduction}

Bovine anaplasmosis occurs in tropical and subtropical areas throughout the world and the disease is a major constraint to cattle production in many countries, occurring endemically in cattle of Mexico, Central and South America and the Caribbean (KOCAN et al., 2010). However, the seroprevalence rates of $A$. marginale vary widely among countries and the variability of these rates contributes to the development of geographically stable enzootic regions (OLIVEIRA et al., 2011).

Anaplasma marginale can be transmitted through biological, mechanical and transplacental routes. In transplacental transmission, infected erythrocytes move across the placenta in the uterus from infected cows to their offspring, without amplification of A. marginale. The importance of each mode of transmission of $A$. marginale is still little known in Brazil. However, new studies have shown a large percentual of infected-born calves in endemic areas in Brazil and South Africa (POHL et al., 2013; POTGIETER; VAN RENSBURG, 1987).

Besides the transmission, age, breed, vector infestation and stocking density are other important factors in the epidemiology of anaplasmosis. Successful management of anaplasmosis depends on adequate knowledge of prevalence and the risk factors associated with the transmission (ALONSO et al., 1992). However, according to UrdazRodríguez et al. (2009) it is difficult to understand clearly the factors associated with acquisition of infection by a cross-sectional study of antibody prevalence.

Diagnosis of bovine anaplasmosis can be made by blood smears, serological and molecular techniques. Giemsa-stained blood smears are used to perform the diagnosis in clinically infected animals, during the acute phase of the disease; however, it is not reliable for detecting pre-symptomatic or carrier animals. In these instances, the infection is generally diagnosed by serologic detection of antibodies with confirmation by molecular methods. Several serological tests have been employed extensively for epidemiological studies, but the ELISA is currently preferred for identifying infected or exposed animals (OIE, 2008). Polymerase chain reaction (PCR) has also been used in detecting the presence of low-level infection in carrier cattle and tick vectors (KOCAN et al., 2010).

The present work aimed to investigate potential risk factors for anaplasmosis and the occurrence of transplacental transmission by molecular and serological assays in cattle, in a longitudinal study.

\section{Materials and Methods}

\section{Background}

Field activities were conducted from September 2008 to August 2011, at the Dairy Cattle Division of Seropédica Experimental Station, Agricultural Research Corporation of the State of Rio de Janeiro 
(Pesagro- Rio). The experimental area was located in the microregion of the Metropolitan Region of Rio de Janeiro (latitude $22^{\circ} 45^{\prime} \mathrm{S}$ and longitude $43^{\circ}$ 41' $\mathrm{W}$ and altitude $33 \mathrm{~m}$ ).

\section{Field blood samples}

By means of proportional stratified sampling, 22 calves were randomly selected. Blood samples were collected every thirty days from birth until the four year of age. Blood was collected from calves at birth (before colostrum suckling) to assess the occurrence of transplacental transmission of A. marginale. Blood was collected from the caudal or jugular vein of individual cattle with EDTA or without; for serum samples, collected blood was incubated at room temperature for $2 \mathrm{~h}$, centrifuged at 3000rpm for $10 \mathrm{~min}$ and stored at $-20^{\circ} \mathrm{C}$ until use. Giemsastained blood smears were analysed by microscopic examination. DNA was extracted from $200 \mu \mathrm{L}$ of each 500 EDTA-whole blood sample using the QIAamp DNA Blood Mini kit (QIAGEN, Valencia, California, USA) according to the manufacturer's instructions.

\section{Enzyme-linked immunosorbent assay (ELISA)}

The A. marginale antigen was prepared by inoculation intravenously in a splenectomized threemonth-old calf, negative for hemoparasites by PCR and serology. Microscopic examination of Giemsastained (Sigma-Aldrich ${ }^{\circledR}$, St. Louis, Missouri 6050, USA) blood smears was performed twice a day to check for the presence of parasites. The rickettsemia peaked on the fifth day after inoculation. Crude antigen production for sensibilization of ELISA plates was performed to Machado et al. (1997).

Thirty serum samples obtained from calves before colostrum suckling were used as negative controls. A group consisting of 30 buffalo serum samples tested positive for $A$. marginale (titres of 1600 by IFAT) were used as positive controls.
Briefly, $100 \mu \mathrm{l}$ of antigen diluted in $0.05 \mathrm{M}$ carbonate/bicarbonate buffer, $\mathrm{pH}$ 9.6, was added to each well of a micro-ELISA plate (Immulon (); Dynatech Laboratories Inc.) and protein concentration was adjusted to $10 \mu \mathrm{g} / \mathrm{mL}$. Plates were sealed and incubated overnight at $4^{\circ} \mathrm{C}$. Plates were blocked for $1 \mathrm{~h}$ at $37^{\circ} \mathrm{C}$ in a humid chamber with $3 \%$ ovalbumin in carbonate/bicarbonate buffer. After five washes with buffer (phosphatebuffered saline, $\mathrm{pH} 7.2$, and $0.05 \%$ Tween 20, PBS-Tween), $100 \mu 1$ of diluted bovine sera (1:400) in PBS-Tween plus $5 \%$ normal rabbit serum were added in duplicate to the ELISA plate. Plates were incubated at $37^{\circ} \mathrm{C}$ in a humid chamber for $90 \mathrm{~min}$ and then washed five times with PBS-Tween. A $100 \mu$ l aliquot of a 1:10000 dilution of alkaline phosphatase conjugated anti-bovine IgG (Sigma Chemical Co.) was added to each well and the plates were incubated at $37^{\circ} \mathrm{C}$ under the same conditions for $90 \mathrm{~min}$. Plates were washed five times with PBS-Tween. The appropriate substrate (p-nitrophenyi phosphate) was added and the plates were sealed and incubated for $40 \mathrm{~min}$ at room temperature. Finally, plates were read at 405 $\mathrm{nm}$ wavelength on a micro-ELISA reader (B.T.100; Embrabio, São Paulo, Brazil). Cut-off values were calculated based on 30 non- Anaplasma marginale-infected water buffaloes sera by the receiver operating characteristic (ROC) analysis with MedCalc statistical software (version 11.4; http://www.medcalc.be) (TERKAWI et al., 2011).

\section{Semi-nested PCR}

Initially, the detection of the presence of $A$. marginale DNA was made using $1.0 \mu 1$ each (20pmol) of primers targeting part of $m s p-5$ gene (a fragment of approximately $458 \mathrm{bp}$ ), namely Amar msp-5 eF (5' GCATAG CCT CCG CGT CTT TC 3') and Amar msp5 eR (5', TCC TCG CCT TGG CCC TCA GA 3'), previously described by de Torioni De Echaide et al. (1998) and optimized by Singh et al. (2012). PCR amplifications were performed at $94^{\circ} \mathrm{C}$ for $1 \mathrm{~min}$ followed by 34 repetitive cycles 
of $94^{\circ} \mathrm{C}$ for $30 \mathrm{~min}, 58^{\circ} \mathrm{C}$ for $30 \mathrm{~min}$, and $72^{\circ} \mathrm{C}$ for $1 \mathrm{~min}$, followed by a final extension at $72^{\circ} \mathrm{C}$ for $10 \mathrm{~min}$ (SINGH et al., 2012). Each sample of extracted DNA was used as a template in $25 \mu \mathrm{L}$ reaction mixtures containing $10 \mathrm{X}$ PCR buffer, $1.5 \mathrm{mM} \mathrm{MgCl} 2, \quad 0.5 \mathrm{mM}$ desoxynucleotide triphosphate (dNTPs) mixture, 1.0 UTaq DNA Polymerase (Invitrogen, Carlsbad, California, USA). Amplified products from the first reaction were used in another using primers Amar msp5 eR (5' TCC TCG CCT TGG CCC TCA GA 3') and Amar msp5 if (5' TAC ACG TGC CCT ACC GAG TTA 3') to a fragment of approximately $345 \mathrm{bp}$ (SINGH et al., 2012). The cycling conditions were the same for the PCR with primers Amar msp-5 eF and Amar msp5 eR. Ultra-pure sterile water was used as negative control. In order to prevent PCR contamination, DNA extraction, reaction setup, PCR amplification and electrophoresis were performed in separated rooms.

\section{Categorization of risk factors evaluated}

Risk factors, namely breed, class, number of ticks and stocking rate were categorized. Regarding the breed standard, six were pure taurine (Holstein), six were F1 (1/2 taurine $\mathrm{x} 1 / 2$ zebuine), six Girolando ( $5 / 8$ zebuine x $3 / 8$ taurine), and six pure zebuine (Gir). Regarding the class, the animals were classified as calves, heifers, pregnant and lactating cows. Their tick infestation was as follows: light infestation ( $<10$ ticks/animal), moderate infestation (10 to 30 ticks/animal) and high infestation ( $>$ 30 ticks/animal). Regarding stocking density, 50 animals were kept in a low-density system (1 AU/ ha), 50 in a medium-density system ( $2 \mathrm{AU} / \mathrm{ha})$, and 50 in a high-density system (5 AU/ha).

\section{Statistical analysis}

The data gathered in relation to the prevalence of $A$. marginale and its influencing determinants, including tick infestation by Rhipicephalus microplus (BARROS-BATTESTI; ARZUA; BECHARA, 2006), class, breed and stocking rate were analyzed using multiple logistic regression. Associations between the prevalence and its possible influencing determinants were measured by means of odds ratios (ORs). The kappa coefficient was calculated to evaluate the agreement among the nPCR, ELISA, and blood smears techniques. The chi-square test was used to evaluate significant differences $(\mathrm{P}<0.05)$ of infection rate in animals by A. marginale of different breed, class, tick infestation and stocking rate. The operational procedures were done using the $\mathrm{R}$ statistical software (R Foundation for Statistical Computing, version 2.12.2, 2011).

\section{Results and Discussion}

\section{Transplacental transmission}

DNA amplification results revealed presence of A. marginale DNA in $41 \%(9 / 22)$ of the newborn calves' blood samples. These results suggest a high prevalence of transplacental transmission in the studied herd. No calve died during the study, although a high number of animals have been infected still in the uterus.

Previously, a percentage of $40 \%$ of calves showed A. marginale-PCR positive results in the first day after birth in a study done in Rio de Janeiro (SILVA et al., 2013). On the other hand, $13 \%$ of calves sampled in the state of Minas Gerais showed $A$. marginale-PCR positive results at the time of birth (POHL et al., 2013). In South Africa, a rate of 15.6\% of tranplascental transmission was found among 77 calves borne from cows showing chronic infection or primo-infected during pregnancy (POTGIETER; VAN RENSBURG, 1987). In Cuba, transplacental transmision was found in $86.4 \%$ (32/37) of calves borned from cows showing clinical anaplasmosis in the last months of pregnancy (SALABARRIA; PINO, 1988). Thus, transplacental transmission may contribute to the epidemiology of anaplasmosis in endemic areas. 


\section{Seroprevalence and risk factors}

The overall seroprevalence for $A$. marginale was $75 \%$ (Table 1). During the primary screening, all factors were found to be significant $(p<0.05)$. These were class $(p<0.005)$, breed $(p<0.000$ to all), tick infestation $(\mathrm{p}<0.192$ to all) and stocking density $(p<0.004$ to density high) (Tab. 1).

The found seroprevalence ( $75 \%$ ) was similar to that observed in Costa Rica (87.5\%) (SHEBISH; VEMULAPALLI; OSETO, 2012), Mozambique (89.1\%) (TEMBUE et al., 2011), Brazil (97\%) (BARROS et al., 2005), Kenya (89\%) (MALOO et al., 2001), El Salvador (78.5\%) (PAYNE; SCOTT, 1982) and Colombia (90.3\%) (PATARROYO; VILLA; DIAZGRANADOS, 1978). However, it was higher than that found in Tanzania (20\% and $37 \%$ ) (SWAI et al., 2005), Puerto Rico (27.4\%) (URDAZ-RODRÍGUEZ et al., 2009) and Costa Rica (37.2\%) (OLIVEIRA et al., 2011).

The age-specific seroprevalence was $26.1 \%$ in calves, $66.3 \%$ in heifers, $55 \%$ in pregnant cows and $64 \%$ in lactation cows. Genetic and environmental factors showing a clear association with seroprevalence included: breed (B. taurus) $(\mathrm{OR}=22.0)$, tick infestation $(>30$ tick/animal $)$ $(\mathrm{OR}=3.4)$ and stocking density $(>5 \mathrm{AU} / \mathrm{ha})(\mathrm{OR}=$
1.2) (Table 2).

Three factors (breed, tick infestation and stocking density) showed a significant effect $(p<0.05)$ in the model of the log regression (Table 2). According to this model, odds of seropositivity tended to increase in the presence of tick $(\mathrm{OR}=3.4), B$. taurus cows $(\mathrm{OR}=36.2)$ and high animal density $(\mathrm{OR}=3.3)$ (Table 2).

Herein, the found seroprevalence was lower in younger animals, consistent with a previous sectional study in Costa Rica (PÉREZ; LEROY; CARRILLO, 1980; OLIVEIRA et al., 2011). Previous studies has shown that the age is a determining factor in the immunity of animals to $A$. marginale, since young animals are more resistant to primary infection because of maternal antibodies (HUGH-JONES et al., 1988; KOCAN et al., 2003; BARROS et al., 2005). However, several studies regarding seroprevalence of $A$. marginale among cattle in Brazil increases with age (SOUZA et al., 2001; PACHECO et al., 2004; BARROS et al., 2005). Young animals probably become infected early (15-60 days of age), becoming resistant to the disease when adults. However, overtime lack of exposure to vectors precludes reinfections in adult cattle, making animals susceptible to clinical disease. 
Table 1. Factors evaluated by the chi-square test in order to verify association with antibodies to A. marginale in 22 cattle, Pesagro-Rio, Brazil, from September 2008 to August 2011.

\begin{tabular}{lccllll}
\hline Risk factors & $\mathrm{N}$ & $\mathrm{P}(\%)$ & $\chi^{2}$ & $\mathrm{OD}$ & $\mathrm{P}=$ value & CI 95\% \\
\hline Class & & & & & & \\
Calves* & 264 & $26,1 \%$ & - & - & - & - \\
Heifers & 264 & $66,3 \%$ & 2,5 & 0,39 & 0,005 & {$[0,29-0,60]$} \\
Pregnants & 264 & $55,0 \%$ & 1,7 & 0,47 & 0,005 & {$[0,80-2,86]$} \\
Lactating & 264 & $64,0 \%$ & 2,3 & 0,40 & 0,005 & {$[0,47-0,91]$} \\
Breed & & & & & & \\
Bos indicus* & 216 & $75,7 \%$ & - & - & - & - \\
F1 & 216 & $76,7 \%$ & 2,1 & 5,51 & 0,000 & {$[2,14-5,16]$} \\
Girolandos & 180 & $42,9 \%$ & 12,4 & 4,08 & 0,000 & {$[1,50-5,20]$} \\
Bos Taurus & 180 & $33,3 \%$ & 16,9 & 22,00 & 0,000 & {$[1,57-4,00]$} \\
R. microplus & & & & & & \\
Low* & 440 & $68 \%$ & - & - & - & {$[0,36-1,28]$} \\
Moderate & 257 & $65 \%$ & 1,5 & 0,69 & 0,217 & {$[0,18-2,11]$} \\
High & 95 & $75 \%$ & 0,5 & 0,70 & 0,192 & - \\
Animal stocking & & & & & & {$[0,64-0,92]$} \\
Low* & 528 & $54 \%$ & - & - & - & 0,041 \\
Moderate & 132 & $69 \%$ & 3,73 & 0,78 & 0,004 & \\
High & 88 & $75 \%$ & 8,86 & 0,72 & $0,8,72]$ \\
\hline
\end{tabular}

Reference value, $\mathrm{N}=$ number of animals evaluated, $\mathrm{P}(\%)=$ prevalence of seropositive to $A$. marginale, $\chi 2=$ chi-square, $\mathrm{OR}=\mathrm{Odds}$ ratio, $\mathrm{CI}=$ confidence interval

Source: Elaboration of the authors.

Table 2. Final multivariable logistic regression model for antibodies to A. marginale in 22 cattle, Pesagro-Rio, Brazil, from September 2008 to August 2011.

\begin{tabular}{lllll}
\hline Risk factors & Category & p-value & OR & CI 95\% \\
Class & Calves* & - & - & - \\
& Heifers & 0,020 & 0,06 & {$[0,016-1,236]$} \\
& Pregnants & 0,361 & 0,54 & {$[0,148-2,005]$} \\
\multirow{3}{*}{ Breed } & Lactating & 0,020 & 0,41 & {$[0,821-1,102]$} \\
& B. taurus* & - & - & - \\
& FI & 0,000 & 4,60 & {$[1,908-11,09]$} \\
& Girolandos & 0,000 & 7,50 & {$[2,684-9,973]$} \\
\multirow{3}{*}{ R. microplus } & B. indicus & 0,000 & 36,20 & {$[10,67-32,87]$} \\
& Low* & - & - & - \\
\multirow{5}{*}{ Animal stocking } & Moderate & 0,000 & 2,70 & {$[11,92-22,08]$} \\
& High & 0,000 & 3,44 & {$[24,08-84,78]$} \\
& Low* & - & - & - \\
& Moderate & 0,982 & 1,18 & {$[0,560-1,889]$} \\
\hline
\end{tabular}

Reference value, $\mathrm{N}=$ number of animals evaluated, $\mathrm{P}(\%)=$ prevalence of seropositive to $A$. marginale, $\chi 2=$ chi-square, $\mathrm{OR}=\mathrm{Odds}$ ratio, $\mathrm{CI}=$ confidence interval

Source: Elaboration of the authors. 
In our study, another important risk factor for anaplasmosis was breed. While taurine-cross cattle shows a higher sensibility to A. marginale, zebucross are more resistant to this pathogen. According to Jonsson, Bock e Jorgensen (2008), zebu-cross cattle have developed resistant to both ticks and anaplasmosis in endemic areas. Conversely, highly specialized susceptible cattle from low endemicity areas are subject to great risk when introduced to high endemicity or places where tick populations fluctuate during the year. This phenomenon has been clearly verified in Mexico, where up to $30 \%$ of susceptible cattle have died in outbreaks of anaplasmosis (ALMAZÁN et al., 2008).

Also, tick infestation showed to be an important risk factor for anaplasmosis in the present study. Similarly, Urdaz-Rodriguez et al. (2009) found highest risk for increased seroprevalence for $A$. marginale in herds with tick infestation high. In our study, $59 \%$ of animals showing tick infestation presented primary infection by $A$. marginale. In Argentina, a strong relationship between the presence of antibodies to $A$. marginale and tick infestation was verified (HABICH et al., 1982). On the other hand, no relationship was found between tick infestation and anaplasmosis among cattle in Costa Rica (PÉREZ; LEROY; CARRILLO, 1980).

Possibly, the low exposure of studied herds to vectors is responsible for an insufficient maintenance of a regular transmission of $A$. marginale. (HUGHJONES et al., 1988; GUGLIELMONE, 1995). In this case, an imbalance caused by the parasite-host relationship due to infrequent transmission creates an artificial endemic instability condition, in which clinical cases occur seasonally coinciding with the maximum activity period of the vectors (PÉREZ; LEROY; CARRILLO, 1980).

Animals maintained in stoking densities $\geq 5$ showed 3.28 higher risk than that ones maintained in stoking densities $\leq 1$. This finding is in accordance with Rogers, Blight and Knott (1978) in Queensland and Pérez et al. (1994) in Costa Rica, who considered that high stocking density was one of the main factors contributing to a high herd seroprevalence to $A$. marginale. When animals are maintained on high density, vectors of $A$. marginale have a higher probability of finding susceptible animals (RODRÍGUEZ-VIVAS et al., 2004).

\section{Correlation in microscopic examination, serological and molecular assays}

In the current study, it was not possible to make the confirmation of the intrauterine infection of $A$. marginale by microscopic examination of calves'blood smears. For this reason, the number of animals with intrauterine infection was made by PCR. Despite of that, 91\% (20/22) of sampled animals showed positive results at blood smears examination before the fourth month of age (Figure 1).

The presence of $A$. marginale was detected in blood smears of calves showing clinical signs such as fever, anemia, abortion or preterm birth and marked weight loss (OLIVEIRA et al., 2009). Some of those animals showed mixed infection with A. marginale, Trypanosoma vivax and Babesia bovis (OLIVEIRA et al., 2009). Because of that, the above authors highlight the role of molecular assays in improvement of diagnosis of haemoparasites.

Although the molecular approach (nPCR) used in the present study detected higher positive numbers of animals parasitized by $A$. marginale when compared to serological assay utilized (ELISA), results obtained from both tests were highly concordant, as determined by the kappa value (0.78). As expected, nPCR assay detected higher positive number of animals parasitized by $A$. marginale than that found by microscopic examination of blood smears. However, the results obtained were concordant for these both direct tests, as determined by the kappa values (0.58). 
Figure 1. Diagnosis of $A$. marginale infection by blood smears examination, PCR and ELISA in blood samples from 22 calves evaluated monthly during the first four months old, Pesagro-Rio, Brazil, from September 2008 to January 2009.

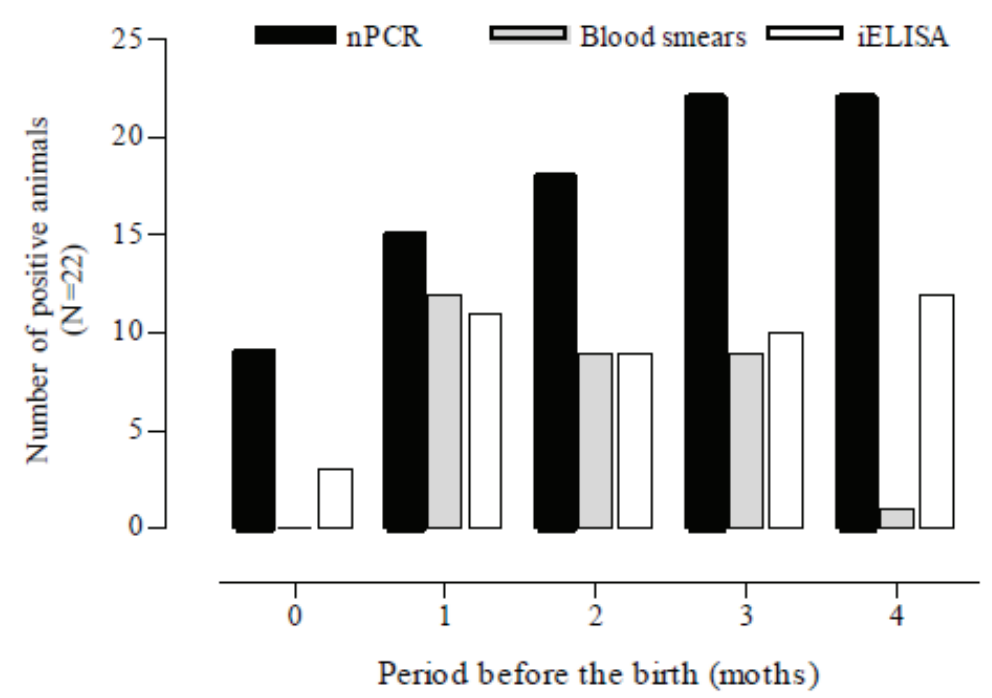

Source: Elaboration of the authors.

\section{Conclusions}

1. Although the studied herd was comprised by apparently asymptomatic animals, A. marginale transplacental transmission showed to be epidemiologically important for the maintainance of the agent through different generations;

2. Tick infestation was correlated to the presence of antibodies to Anaplasma marginale. Probably, a minimal tick infestation is needed for $A$. marginale exposure, which should be enough to estimulate the humoral immune response of infected animals.

3. Although the area where animals were sampled is considered endemic stable for A. marginale, the herd analysed in the present study was characterized as an unstable. For this reason, epidemiological studies should consider a farm as an "epidemiological unity", where different risk factors may take account in the occurrence of $A$. marginale.

\section{Acknowledgements}

We are grateful to Dr. Rosangela Zacarias Machado by kindly supplied the antigen used. We also thank the Coordination for the Improvement of Higher Level of Education Personnel (CAPES) and National Counsel of Technological and Scientific Development (CNPq) for financial support.

\section{References}

ALMAZÁN, C.; MEDRANO, C.; ORTIZ, M.; DE LA FUENTE, J. Genetic diversity of Anaplasma marginale strains from an acute bovine anaplasmosis outbreak within a herd in an endemic area. Veterinary Parasitology, Amsterdam, v. 158, n. 1, p. 103-109, nov. 2008.

ALONSO, M.; ARELLANO-SOTA, C.; CERESER, V. H.; CORDOVES, C. O.; GUGLIELMONE, A. A.; KESSLER, R. H.; MANGOLD, A. J.; NARI, A.; PATARROYO, J. H.; SOLARI, M. A. Epidemiology of bovine anaplasmosis and babesiosis in Latin America and the Caribbean. Scientific and Technical Review, Roma, v. 11, n. 3, p. 713-733, sept. 1992.

BARROS, S. L.; MADRUGA, C. R.; ARAÚJO, F. R.; MENK, C. F.; DE ALMEIDA, M. A. O.; MELO, E. P. S.; KESSLER, R. H. Serological survey of Babesia bovis, Babesia bigemina, and Anaplasma marginale antibodies in cattle from the semi-arid region of the state of Bahia, Brazil, by enzyme-linked inmunosorbent assays. Memórias do Instituto Oswaldo Cruz, Rio de Janeiro, v. 100 , n. 6, p. 513-517, oct. 2005. 
BARROS-BATTESTI,D.M.;ARZUA,M.;BECHARA, G. H. Carrapatos de importância médico -veterinária da região neotropical - um guia ilustrado para identificação de espécies. São Paulo: Vox/ICTTD-3/Butantan, 2006. $223 \mathrm{p}$.

GUGLIELMONE, A. A. Epidemiology of babesiosis and anaplasmosis in South and Central America. Veterinary Parasitology, Amsterdam, v. 57, n. 1, p. 109-119, mar. 1995.

HABICH, G. E.; DE RIOS, L. G.; HADANI, A.; CONDRON, R. J.; DE HAAN, L.; BROADBENT, D. W. Estudios sobre sanidad animal en el noroeste argentino. VIII. Prevalencia de animales con anticuerpos séricos contra Babesia bovis y Anaplasma marginale en tambos de Catamarca, Salta y Tucumán. Revue de Médecine Vétérinaire, Buenos Aires, v. 1, n. 63, p. 316-329, 1982.

HUGH-JONES, M. E.; SCOTLAND, K.; APPLEWHAITE, L. M.; ALEXANDER, M. Seroprevalence of anaplasmosis and babesiosis in livestock on St. Lucia, 1983. Tropical Animal Health Production, Edinburgh, v. 1, n. 20, p. 137-139, 1988b.

JONSSON, N. N.; BOCK, R. E.; JORGENSEN, W. K. Productivity and health effects of anaplasmosis and babesiosis on Bos indicus cattle and their crosses, and the effects of differing intensity of tick control in Australia. Veterinary Parasitology, Amsterdam, v. 1, n. 155, p. 1-9, aug. 2008.

KOCAN, K. M.; DE LA FUENTE, J. C.; BLOUIN, E. F.; COETZEE, J. F.; EWING, S. A. The natural history of Anaplasma marginale. Veterinary Parasitology, Amsterdam, v. 10, n. 167, p. 95-107, feb. 2010.

KOCAN, K. M.; DE LA FUENTE, J.; GUGLIELMONE, A. A.; MELÉNDEZ, R. D. Antigens and alternatives for control of Anaplasma marginale infection in cattle. Clinical Microbiology Reviews, Washington, v. 16, n. 4, p. 698-712, oct. 2003.

MACHADO, R. Z.; MONTASSIER, H. J.; PINTO, A. A.; LEMOS, E. G.; MACHADO, M. R. F.; VALADÃO, I. F. F.; BARCI, L. G.; MALHEIROS, E. B. An Enzymelinked Immunosorbent Assay (ELISA) for the detection of antibodies against Babesia bovis in cattle. Veterinary Parasitology, Amsterdam, v. 71, n. 1, p. 17-26, 1997.

MALOO, S. H.; ROWLANDS, G. J.; THORPE, W.; GETTINBY, G.; PERRY, B. D. A longitudinal study of disease incidence and case-fatality risks on small-holder dairy farms in coastal Kenya. Preventive Veterinary Medicine, Colorado, v. 2, n. 52, p. 17-29, nov. 2001.

OLIVEIRA, J. B.; HERNÁNDEZ-GAMBOA, J.; JIMÉNEZ-ALFARO, C.; ZELEDÓN, R.; BLANDÓN, M.; URBINA, A. First report of Trypanosoma vivax infection in dairy cattle from Costa Rica. Veterinary Parasitology, Amsterdam, v. 7, n. 163, p. 136-139, jul. 2009.

OLIVEIRA, J. B.; MONTOYA, J.; ROMERO, J. J.; URBINA, A.; SOTO-BARRIENTOS, N.; MELO, E. S. P.; RAMOS, C. A. N.; ARAÚJO, F. R. Epidemiology of bovine anaplasmosis in dairy herds from Costa Rica. Veterinary Parasitology, Amsterdam, v. 11, n. 177, p. 359-365, may 2011.

PACHECO, R. C.; VIDOTTO, O.; TAMEKUNI, K.; IGARASHI, M.; KAWASAKI, P.; PRUDENCIO, L. B.; MARANA, E. R. M.; PEREIRA, A. L. Dinamica da infeccao natural pelo Anaplasma marginale em vacas e bezerros da raca Holandesa, na regiao de Londrina, Estado do Paraná, Brasil. Semina Ciências Agrárias, Londrina, v. 25, n. 3, p. 235-244. 2004.

PATARROYO, J. H.; VILLA, O.; DIAZGRANADOS, H. Epidemiology of cattle anaplasmosis in Colombia: 1. Prevalence distribution of agglutinating antibodies. Tropical Animal Health Production, Edinburgh, v. 10, n. 3, p. 171-174, aug. 1978.

PAYNE, R. C.; SCOTT, J. M. Anaplasmosis and babesiosis in El Salvador. Tropical Animal Health Production, Edinburgh, v. 14, n. 2, p. 75-80, may 1982.

PÉREZ, E.; HERRERO, M. V.; JIMÉNEZ, C.; HIRD, D.; BUENING, G. B. Effect of management and host factors on seroprevalence of bovine anaplasmosis and babesiosis in Costa Rica. Preventive Veterinary Medicine, Colorado, v. 20, n. 1, p. 33-46, jul. 1994.

PÉREZ, E.; LEROY, E.; CARRILLO, M. Anaplasmosis y piroplasmosis: estudio epidemiológico en la estación experimental "Los Diamantes". Ciencias Veterinarias Heredia, Ciudad de Mexico, v. 2, n. 1, p. 7-20, 1980.

POHL, A. E.; CABEZAS-CRUZ, A.; RIBEIRO, M. F. B.; SILVEIRA, J. A. G.; PFISTER, C. S. K.; PASSOS, L. M. F. Detection of genetic diversity of Anaplasma marginale isolates in Minas Gerais, Brazil. Revista Brasileira Parasitologia Veterinária, Jaboticabal, v. 22, n. 1, p. 129-135, jan./mar. 2013.

POTGIETER, F. T.; VAN RENSBURG, L. The persistence of colostral Anaplasma antibodies in incidence of in utero transmission of Anaplasma infections in calves under laboratory conditions. The Onderstepoort Journal of Veterinary Research, Durbanville, v. 54, n. 4, p. 557560, dec. 1987.

RODRÍGUEZ-VIVAS, R. I.; MATA, Y.; PÉREZ, E.; WAGNER, G. The effect of management factors on the seroprevalence of Anaplasma marginale in Bos indicus cattle in the Mexican Tropics. Tropical Animal Health Production, Edinburgh, v. 36, n. 2, p. 135-143, feb. 2004. 
ROGERS, R. J.; BLIGHT, G. W.; KNOTT, S. G. A study of the epidemiology of Anaplasma marginale infections of cattle in southern Queensland: clinical disease and the prevalence of complement fixing antibodies. Australian Veterinary Journal, Malden, v. 54, n. 3, p. 115-120, mar. 1978.

SALABARRIA, F. F.; PINO, R. Vertical transmission of Anaplasma marginale in cows affected in late pregnancy. Revista Cubana de Ciencias Veterinarias, Habana, v. 19, n. 1, p. 179-182, 1988.

SHEBISH, E.; VEMUlAPALli, R.; OSETO, C. Prevalence and molecular detection of Anaplasma marginale, Babesia bovis and Babesia bigemina in cattle from Puntarenas Province, Costa Rica. Veterinary Parasitology, Amsterdam, v. 188, n. 1, p. 164-167, aug. 2012.

SILVA, J. B.; LOPES, C. T. A.; PINHEIRO, C. P.; SILVA, R. S. L.; FONSECA, A. H.; ARAÚJO, F. R.; BARBOSANETO, J. D. Prevalência sorológica e molecular de Babesia bovis e Babesia bigemina em búfalos (Bubalus bubalis)na Ilha de Marajó, Pará. Pesquisa Veterinária Brasileira, Seropédica, v. 33, n. 7, p. 847-850, 2013.

SINGH, H.; JYOTI, H. M.; SINGH, N. K.; RATH, S. S. Molecular detection of Anaplasma marginale infection in carrier cattle. Ticks and Tick-borne Diseases, Lippersdorf, v. 3, n. 1, p. 55-58, feb. 2012.

SOUZA, J. C. P.; SOARES, C. O.; MADRUGA, C. R.; MASSARD, C. L. Prevalência de anticorpos anti Anaplasma marginale (Rickettsiales: Anaplasmataceae) em bovinos na mesorregiao do médio paraiba. Ciência Rural, Santa Maria, v. 31, n. 2, p. 309-314. 2001.

SWAI, E. S.; KARIMURIBO, E. D.; OGDEN, N. H.; FRENCH, N. P.; FITZPATRICK, J. L.; BRYANT, M. J.; KAMBARAGE, D. M. Seroprevalence estimation and risk factors for $A$. marginale on smallholder dairy farms in Tanzania. Tropical Animal Health Production, Edinburgh, v. 37, n. 8, p. 599-610, nov. 2005.
TEMBUE, A. A. M.; SILVA. J. B.; SILVA. F. J. M.; PIRES, M. S.; BALDANI, C. D.; SOARES, C. O.; MASSARD, C. L.; FONSECA, A. F. Seroprevalence of $\operatorname{IgG}$ antibodies against Anaplasma marginale in cattle from south Mozambique. Revista Brasileira Parasitologia Veterinária, Jaboticabal, v. 20, n. 4, p. 1-7, dec. 2011.

TERKAWI, M. A.; HUYEN, N. X.; SHINUO, C.; INPANKAEW, T.; MAKLON, K.; ABOULAILA, M.; UENO, A.; GOO, Y. K.; YOKOYAMA, N.; JITTAPALAPONG, S.; XUAN, X.; IGARASHI, I. Molecular and serological prevalence of Babesia bovis and Babesia bigemina in water buffaloes in the northeast region of Thailand. Veterinary Parasitology, Amsterdam, v. 10, n. 178, p. 201-207, jun. 2011.

TORIONI DE ECHAIDE, S.; KNOWLES, D. P.; MCGUIRE, T. C.; PALMER, G. H.; SUAREZ, C. E.; MCELWAIN, T. F. Detection of cattle naturally infected with Anaplasma marginale in a Region of endemicity by nested PCR and Competitive enzyme-linked immunosorbent assay using recombinant major surface protein 5. Journal of Clinical Microbiology, Washington, v. 36, n. 3, p. 777-782, 1998.

URDAZ-RODRÍGUEZ， J. H.; FOSGATE， G. T.; ALLEMAN, A. R.; RAE, D. O.; DONOVAN, G. A.; MELENDEZ, P. Seroprevalence estimation and management factors associated with high herd seropositivity for Anaplasma marginale in commercial dairy farms of Puerto Rico. Tropical Animal Health Production, Edinburgh, v. 41, n. 7, p. 1439-1448, oct. 2009.

WORLD ORGANIZATION FOR ANIMAL HEALTH - OIE. Chapter 2.4.1 bovine. In: MCELWAIN, T. F. Manual of diagnostic tests and vaccines for terrestrial animals. $6^{\text {th }}$ ed. Paris: World Organization for Animal Health, 2008. p. 599-610. 